
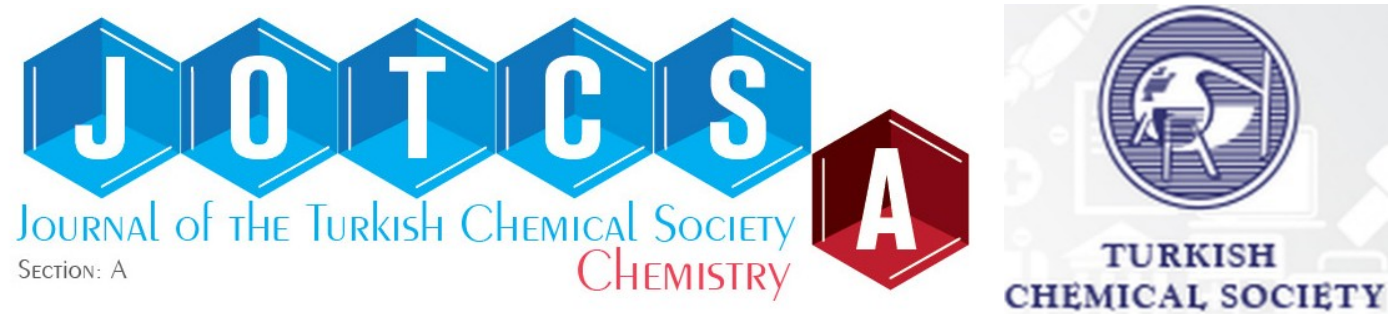

\title{
Inhibitory effects of novel benzamide derivatives towards acetylcholinesterase enzyme
}

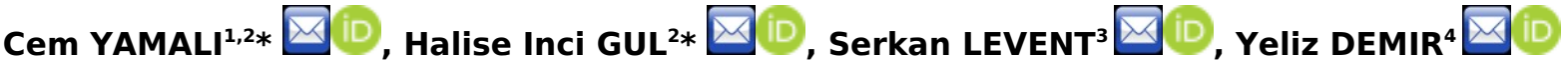

\begin{abstract}
${ }^{1}$ Department of Basic Pharmaceutical Sciences, Faculty of Pharmacy, Cukurova University, Adana, Turkey
${ }^{2}$ Department of Pharmaceutical Chemistry, Faculty of Pharmacy, Ataturk University, Erzurum, Turkey

${ }^{3}$ Department of Pharmaceutical Chemistry, Faculty of Pharmacy, Anadolu University, Eskişehir, Turkey

${ }^{4}$ Department of Pharmacy Services, Nihat Delibalta Gole Vocational High School, Ardahan University, Ardahan, Turkey
\end{abstract}

\begin{abstract}
Alzheimer's disease is one of the diseases which is identified by progressive memory loss and cognitive deficits leading to a decline in the lifespan of the patients. The drugs used in the clinic show palliative properties and they are unable to modify disease progression. In this study, $N$ - $(4-(N-$ (diaminomethylene)sulfamoyl)phenyl)-2-(substituted-benzamido)benzamide derivatives were synthesized and evaluated towards acetylcholinesterase (AChE, E.C.3.1.1.7) enzyme which is the most studied enzyme regarding Alzheimer's disease. The inhibition constants $(\mathrm{Ki})$ of the compounds synthesized towards the AChE enzyme were in the range of $15.51 \pm 1.88-41.24 \pm 10.13 \mathrm{nM}$. The most effective compound with the lowest $\mathrm{Ki}=15.51 \pm 1.88 \mathrm{nM}$, 2-benzamido- $N$-(4-( $N$-(diaminomethylene)sulfamoyl)phenyl)benzamide $\mathbf{6}$, can be reported as a lead compound of this study. Bioactivity results obtained by this study may provide useful information on the development of novel and potent inhibitors targeting Alzheimer's disease.
\end{abstract}

Keywords: Acetylcholinesterase, benzamide, sulfaguanidine, Alzheimer's disease.

Submitted: December 17, 2020. Accepted: February 08, 2021.

Cite this: Yamali C, Gul HI, Levent S, Demir Y. Inhibitory effects of novel benzamide derivatives towards acetylcholinesterase enzyme. JOTCSA. 2021;8(2):429-34.

DOI: https://doi.org/10.18596/jotcsa.842465.

*Corresponding authors. E-mail: (c.yamali@yahoo.com) (incigul@atauni.edu.tr)

\section{INTRODUCTION}

Alzheimer's disease (AD) is identified by progressive memory loss and cognitive deficits leading to declining in the lifespan of the patients. Despite its complicated molecular pathogenesis, several treatments have been used at the clinic (1).

Manipulation of cholinergic activity by decreased production of acetylcholine (ACh) or abnormal acetylcholinesterase (AChE) activity is the moststudied clinical approach. Two types of cholinesterases (ChEs) were identified as acetylcholinesterase (AChE) and butyrylcholinesterase (BChE, pseudocholinesterase). Both ChEs have a role in the breakdown of ACh into choline and acetate (2). Cholinesterase inhibitors (ChEls) as drug or drug candidates enhance the synaptic level of ACh by inhibiting ChEs in a dose-dependent manner (3).
According to the cholinergic hypothesis, to design inhibitors as antagonists of AChE and to discover molecules to bind with ACh receptors as agonists are the major strategies to control the amount of ACh in the synaptic cleft (4). Even drugs used in the clinic could improve the cognitive symptoms, they are unable to modify disease progression and they also show a different mode of actions, pharmacokinetics, and side effects. To date, several ChEls are approved for the treatment of AD such as donepezil, rivastigmine, and galantamine. Even tacrine was the first drug used in $A D$, it is no longer used due to severe side effects. Notwithstanding scientific efforts, there is still no effective therapeutics for the prevention and treatment of $A D$ (5-7).

A variety of chemical scaffolds has been reported with anti-AD effects. Benzamide derivative incorporating isoquinoline moiety was reported as the most potent candidate against human AChE with 
$\mathrm{Ki}$ of $6.47 \mathrm{nM}$ (4). As another attractive pharmacophoric group for $A D$, guanidine skeleton shows promising biological activities (8). Hydrazones having guanidine core as butyrylcholinesterase inhibitors (8), and cyclic acyl guanidine carbamate type compounds as ChEls were reported with promising inhibitory potencies (6).

Our research group focused on primary sulfonamide derivatives and their bioactivities on CA I, CA II, CA IX, CA XII, and/or cholinesterase enzymes and their anticancer effects as potent drug candidates (9-12). This is the first study regarding some novel secondary sulfonamides to extend our earlier investigations. Novel sulfaguanidine bearing benzamide derivatives having the chemical structure of $\mathrm{N}-(4-(\mathrm{N}-$ (diaminomethylene)sulfamoyl)phenyl)-2-

(substituted-benzamido)benzamides 6-9 were designed, synthesized, and evaluated towards AChE enzyme to find out novel and potent AChE enzyme inhibitors for further experiments.

\section{EXPERIMENTAL SECTION}

\section{Chemistry}

NMR spectra of the compounds were recorded by Bruker AVANCE III $400 \mathrm{MHz}$ (Bruker, Karlsruhe, Germany) in DMSO - $d 6$ (Merck KGaA, Darmstadt, Germany). LCMS-IT-TOF system (Shimadzu, Tokyo, Japan) was used for HRMS spectra. Electrothermal 9100 (IA9100, Bibby Scientific Limited, Staffordshire, UK) device was used to measure melting points (Mp). TLC-Silicagel HF254 (Merck Art 5715) plate was used to check the reaction process using UV lamp (Spectroline, ENF-240C/ FE, New York, U.S.A). DCM:MeOH mixture was used as a TLC solvent system

Synthesis of 2-(4-substituted phenyl)-4 Hbenzo(d)(1,3)oxazin-4-ones, 2-5 $(13,14)$

Methyl anthranilate (33 g) was stirred in $\mathrm{NaOH}$ solution $(2 \mathrm{~N}, 150 \mathrm{~mL})$ at room temperature for 30 hours. The mixture was poured into $100 \mathrm{~mL}$ of ice water and neutralized by $\mathrm{HCl}(37 \%)$. The white solid 2-aminobenzoic acid (1) was filtered, washed with water, and dried. To a solution of 2-aminobenzoic acid (1, anthranilic acid) (14.6 mmol) in pyridine (30) at $0-5^{\circ} \mathrm{C}$, a suitable benzoyl chloride $(21.9 \mathrm{mmol})$ was added while stirring. After $30 \mathrm{~min}$, the mixture was stirred at room temperature for 3-7 hours. The mixture was then treated with $\mathrm{NaHCO}_{3}$ solution $(10 \%, 50 \mathrm{~mL})$ to remove the unreacted acid. Then the white solid obtained was filtered and washed with water several times to remove excess pyridine. The white color intermediates were used for the next step without further purification since the compounds are single spots on TLC plates. Experimental data for the raw intermediates were given below. Yield $60 \%, \mathrm{mp}=120-122{ }^{\circ} \mathrm{C}$. HRMS (ESI-MS) $\mathrm{C}_{14} \mathrm{H}_{9} \mathrm{NO}_{2} \quad \mathrm{~m} / \mathrm{z}$ Calc. $(\mathrm{M}+\mathrm{H})^{+}$224.0706; Found: 224.0695. Compound 3: Yield 65\%, $\mathrm{mp}=$ 150-151 ${ }^{\circ} \mathrm{C}$. Compound 4: Yield 71\%, $\mathrm{mp}=169-171$
${ }^{\circ} \mathrm{C}$. HRMS (ESI-MS) $\mathrm{C}_{14} \mathrm{H}_{8} \mathrm{NO}_{2} \mathrm{~F} \quad \mathrm{~m} / \mathrm{z}$ Calc. $(\mathrm{M}+\mathrm{H})^{+}$ 242.0612; Found: 242.0623. Compound 5: Yield $64 \%, \mathrm{mp}=90-92{ }^{\circ} \mathrm{C}$. HRMS (ESI-MS) $\mathrm{C}_{15} \mathrm{H}_{8} \mathrm{NO}_{2} \mathrm{~F}_{3} \mathrm{~m} / \mathrm{z}$ Calc. $(\mathrm{M}+\mathrm{H})^{+}$292.0580; Found. 292.0574.

\section{Synthesis of benzamide derivatives 6-9, Figure 1}

Sulfaguanidine $(1 \mathrm{mmol})$ was added into a suitable 2-(4-substituted phenyl)-4H-benzo(d)(1,3)oxazin-4ones (2-5) (1 mmol) solution in hot acetic acid $(20$ $\mathrm{mL})$. The mixture was refluxed for 24 hours. After completion of the reaction, it was poured into cold water $(100 \mathrm{~mL})$. The solid product was precipitated out and filtered. The crude was washed with water and dried. The compounds were purified by crystallization using suitable solvents mentioned below. The chemical structures were confirmed by ${ }^{1} \mathrm{H} N M R,{ }^{13} \mathrm{C} N M R$, and HRMS.

\section{2-Benzamido- $\mathbf{N}-(4-(N-$ (diaminomethylene)sulfamoyl)phenyl)benzami de, 6}

White solid (methanol:DMF:water), $42 \%$ yield, $\mathrm{mp}=$ 294-295 ${ }^{\circ} \mathrm{C}$. ${ }^{1} \mathrm{H}$ NMR (DMSO-d6, $\left.400 \mathrm{MHz}, \mathrm{ppm}\right) \delta$ $11.50(\mathrm{~s}, 1 \mathrm{H},-\mathrm{CONH}-), 10.78(\mathrm{~s}, 1 \mathrm{H},-\mathrm{CONH}-), 8.42$ $(\mathrm{d}, J=8.3 \mathrm{~Hz}, 1 \mathrm{H}, \mathrm{ArH}), 7.94-7.90(\mathrm{~m}, 3 \mathrm{H}, \mathrm{ArH}), 7.86$ $(\mathrm{d}, J=8.7 \mathrm{~Hz}, 2 \mathrm{H}, \mathrm{ArH}), 7.76(\mathrm{~d}, J=8.7 \mathrm{~Hz}, 2 \mathrm{H}$, ArH) , 7.64-7.53 (m, 4H, ArH), $7.29(\mathrm{t}, J=7.5 \mathrm{~Hz}, 1 \mathrm{H}$, ArH), 6.74 (bs, 4H, $-\mathrm{NH}_{2} \times 2$ ). ${ }^{13} \mathrm{C}$ NMR (DMSO-d6, $100 \mathrm{MHz}, \mathrm{ppm}) \delta 168.1,165.2,158.6,141.6,140.2$, $138.9,134.9,132.9,132.5,129.6,129.3,127.6$, $126.9,123.9,123.8,122.1,120.8$. HRMS (ESI-MS) $\mathrm{C}_{21} \mathrm{H}_{19} \mathrm{~N}_{5} \mathrm{O}_{4} \mathrm{~S} \quad \mathrm{~m} / \mathrm{z}$ Calc. $(\mathrm{M}+\mathrm{H})^{+} 438.1231$; Found 438.1232.

N-(4-( $N$-(diaminomethylene)sulfamoyl)phenyl)2-(4-methoxybenzamido) benzamide, 7

White solid (methanol:acetone:water), 33\% yield, $\mathrm{mp}=235-236{ }^{\circ} \mathrm{C} .{ }^{1} \mathrm{H}$ NMR (DMSO-d6, $400 \mathrm{MHz}$, ppm) $\delta 11.43(\mathrm{~s}, 1 \mathrm{H},-\mathrm{CONH}-), 10.76(\mathrm{~s}, 1 \mathrm{H},-\mathrm{CONH}-)$, $8.43(\mathrm{~d}, J=8.3 \mathrm{~Hz}, 1 \mathrm{H}, \mathrm{ArH}), 7.91-7.87(\mathrm{~m}, 3 \mathrm{H}, \mathrm{ArH})$, $7.83(\mathrm{~d}, J=8.7 \mathrm{~Hz}, 2 \mathrm{H}, \mathrm{ArH}), 7.75(\mathrm{~d}, J=8.6 \mathrm{~Hz}, 2 \mathrm{H}$, $\operatorname{ArH}), 7.61(\mathrm{t}, J=7.7 \mathrm{~Hz}, 1 \mathrm{H}, \operatorname{ArH}), 7.28(\mathrm{t}, J=7.7 \mathrm{~Hz}$, $1 \mathrm{H}, \mathrm{ArH}), 7.09(\mathrm{~d}, J=8.3 \mathrm{~Hz}, 2 \mathrm{H}, \mathrm{ArH}), 6.71$ (bs, 4H, $\left.-\mathrm{NH}_{2} \times 2\right), 3.82\left(\mathrm{~s}, 3 \mathrm{H},-\mathrm{OCH}_{3}\right) .{ }^{13} \mathrm{C}$ NMR (DMSO- $d 6$, $100 \mathrm{MHz}, \mathrm{ppm}) \delta 168.2,164.6,162.7,158.6,141.5$, $140.2,139.3,129.6,129.5,129.4,126.9,126.8$, 123.6, 123.2, 121.9, 120.9, 114.6, 55.9. HRMS (ESIMS) $\mathrm{C}_{22} \mathrm{H}_{21} \mathrm{~N}_{5} \mathrm{O}_{5} \mathrm{~S} \mathrm{~m} / \mathrm{z}$ Calc. $(\mathrm{M}+\mathrm{H})^{+}$468.1336; Found 468.1340

N-(4-(N-(diaminomethylene)sulfamoyl)phenyl)2-(4-fluorobenzamido)benzamide, 8

White solid (methanol:DMF:water), $34 \%$ yield, $\mathrm{mp}=$ 285-287 ${ }^{\circ} \mathrm{C}$. ${ }^{1} \mathrm{H}$ NMR (DMSO- $d 6,400 \mathrm{MHz}, \mathrm{ppm}$ ) $\delta$ 11.39 (s, 1H, -CONH-), 10.76 (s, 1H, -CONH-), 8.32 $(\mathrm{d}, J=8.2 \mathrm{~Hz}, 1 \mathrm{H}, \mathrm{ArH}), 7.97(\mathrm{t}, J=6.4 \mathrm{~Hz}, 2 \mathrm{H}, \mathrm{ArH})$, $7.88(\mathrm{~d}, J=7.8 \mathrm{~Hz}, 1 \mathrm{H}, \mathrm{ArH}), 7.81(\mathrm{~d}, J=8.5 \mathrm{~Hz}, 2 \mathrm{H}$, $\mathrm{ArH}), 7.74(\mathrm{~d}, J=8.5 \mathrm{~Hz}, 2 \mathrm{H}, \mathrm{ArH}), 7.62(\mathrm{t}, J=7.6$ $\mathrm{Hz}, 1 \mathrm{H}, \mathrm{ArH}), 7.39(\mathrm{~d}, J=8.5 \mathrm{~Hz}, 2 \mathrm{H}, \operatorname{ArH}), 7.30(\mathrm{t}, J$ $=7.3 \mathrm{~Hz}, 1 \mathrm{H}, \mathrm{ArH}$ ), 6.69 (bs, $4 \mathrm{H},-\mathrm{NH}_{2} \times 2$ ). ${ }^{13} \mathrm{C} \mathrm{NMR}$ (DMSO-d6, $100 \mathrm{MHz}, \mathrm{ppm}) \delta 167.9,164.7\left(\mathrm{~d}, \mathrm{~J}_{\mathrm{CF}}=\right.$ $248 \mathrm{~Hz}), 163.4,158.6,141.6,140.1,138.7,132.8$, $131.4,130.3\left(d, J_{C F}=9 \mathrm{~Hz}\right), 129.6,126.9,124.3$, 
$124.1,122.4,120.8,116.3\left(\mathrm{~d}, J_{\mathrm{CF}}=22 \mathrm{~Hz}\right)$. HRMS (ESI-MS) $\mathrm{C}_{21} \mathrm{H}_{18} \mathrm{~N}_{5} \mathrm{O}_{4} \mathrm{FS} \mathrm{m} / \mathrm{z}$ Calc. $(\mathrm{M}+\mathrm{H})^{+}$456.1136; Found 456.1136 .

$\boldsymbol{N}$-(4-( $\mathbf{N}$-(diaminomethylene)sulfamoyl)phenyl)2-(4(trifluoromethyl) benzamido)benzamide, 9 White solid (methanol:DMF:water), 30\% yield, $\mathrm{mp}=$ 297-299 ${ }^{\circ} \mathrm{C} .{ }^{1} \mathrm{H}$ NMR (DMSO- $d 6,400 \mathrm{MHz}, \mathrm{ppm}$ ) $\delta$ 11.49 (s, 1H, -CONH-), 10.77 (s, 1H, -CONH-), 8.28 $(\mathrm{d}, J=8.2 \mathrm{~Hz}, 1 \mathrm{H}, \mathrm{ArH}), 8.09(\mathrm{~d}, J=8.2 \mathrm{~Hz}, 2 \mathrm{H}, \mathrm{ArH})$, $7.94(\mathrm{~d}, J=8.3 \mathrm{~Hz}, 2 \mathrm{H}, \mathrm{ArH}), 7.89(\mathrm{~d}, J=7.8 \mathrm{~Hz}, 1 \mathrm{H}$, ArH), $7.82(\mathrm{~d}, J=8.7 \mathrm{~Hz}, 2 \mathrm{H}, \mathrm{ArH}), 7.73(\mathrm{~d}, J=8.7$ $\mathrm{Hz}, 2 \mathrm{H}, \mathrm{ArH}), 7.63(\mathrm{t}, J=7.5 \mathrm{~Hz}, 1 \mathrm{H}, \mathrm{ArH}), 7.33(\mathrm{t}, J$ $=7.5 \mathrm{~Hz}, 1 \mathrm{H}, \mathrm{ArH}), 6.69$ (bs, $4 \mathrm{H},-\mathrm{NH}_{2} \times 2$ ). ${ }^{13} \mathrm{C} \mathrm{NMR}$ (DMSO- $d 6,100 \mathrm{MHz}, \mathrm{ppm}) \delta 167.8,164.2,158.6$, $141.6,140.1,138.8,138.2,132.7,132.2\left(d, J_{C F}=32\right.$ $\mathrm{Hz}), 129.6,128.6,126.9,126.3\left(\mathrm{~d}, J_{\mathrm{CF}}=3 \mathrm{~Hz}\right), 124.9$, $124.5,124.3\left(\mathrm{~d}, J_{\mathrm{CF}}=271 \mathrm{~Hz}\right), 122.7,120.7$. HRMS (ESI-MS) $\mathrm{C}_{22} \mathrm{H}_{18} \mathrm{~N}_{5} \mathrm{O}_{4} \mathrm{~F}_{3} \mathrm{~S} \mathrm{~m} / \mathrm{z}$ Calc. $(\mathrm{M}+\mathrm{H})^{+} 506.1111$; Found 506.1104.

\section{AChE inhibition assay}

5,5'-Dithiobis(2-nitrobenzoic acid) (DTNB, D8130), acetylthiocholine iodide (AChI, 01480) and AChE from Electrophorus electricus (C2888, Type V-S), were acquired from Sigma-Aldrich Chemie $\mathrm{GmbH}$ (Taufkirchen, Germany). In vitro effects on AChE activity of the compounds were evaluated according to the Ellman's assay (15) as previously reported $(16,17)$. AChl was used as the substrate at $412 \mathrm{~nm}$. Tacrine (TAC) was used as a control drug. One enzyme unit (EU) was defined as the hydrolysis of $1.0 \mu \mathrm{mol}$ acetylcholine to choline and acetate per minute at $\mathrm{pH}=8$ at $37{ }^{\circ} \mathrm{C}$. All the measurements were repeated three times. The analysis results were expressed as means of triplicate assays \pm SEM.

\section{RESULTS and DISCUSSION}

The novel compounds 6-9 were synthesized in three steps by the method outlined in Figure 1. Firstly, a starting compound methyl anthranilate was hydrolyzed under basic conditions to afford 2aminobenzoic acid, $\mathbf{1}$. The chemical structure was confirmed with NMRs. Methyl peak belonging ester moiety of methyl anthranilate did not appear in ${ }^{1} \mathrm{H}$ NMR spectra. This data showed that methyl anthranilate turned into its acid derivative. In the second step, compound $\mathbf{1}$ was reacted with several benzoyl chlorides in pyridine and the cyclic intermediate compounds, 2-(4-substituted phenyl)$4 \mathrm{H}$-benzo(d)(1,3)oxazin-4-ones (2-5), were isolated from the reaction media. Finally, compounds 2-5 reacted with sulfaguanidine in acetic acid solution by heating to obtain final compounds 6-9.
Different benzoxazine derivatives of intermediates were transformed into the respective quinazolinone derivatives by a condensation reaction with several amine derivatives in pyridine (14) and acetic acid via microwave heating (18). Herein, we isolated and confirmed open-chain forms of the compounds under the conditions applied. Chemical structures of the compounds were elucidated successfully by the spectral methods. According to NMRs and HRMS results of the representative compound $\mathbf{7}$, signals of two amide protons were seen at $11.43 \mathrm{ppm}(\mathrm{s}, 1 \mathrm{H}$, CONH-) and $10.76 \mathrm{ppm}(\mathrm{s}, 1 \mathrm{H},-\mathrm{CONH}-)$. These two protons testified that the isolated compound was not a quinazolinone derivative. Besides, $-\mathrm{NH}_{2}$ protons belong to guanidine moiety was seen as a broad singlet at $6.71 \mathrm{ppm}$. Furthermore, ${ }^{13} \mathrm{C}$ NMR spectra confirmed the chemical structure of compound $\mathbf{7}$ as it showed a total of 18 carbon peaks as expected. Calculated and measured $\mathrm{m} / \mathrm{z}$ values are also compatible in HRMS spectra as reported in the experimental section.

According to our preliminary experiments based on the different projects (unpublished data), we obtained a series of quinazolinone-type benzenesulfonamides in considerable high yields under reflux conditions in acetic acid. In this study, we used sulfaguanidine as another kind of starting compound having primary amine. In the previous study, we easily isolated the ring-closed product after cooled the reaction medium. However, in this study, we isolated open-chain compounds in the same conditions. Reaction time was extended to increase products' yield, however, starting material did not consume totally. Moreover, the reaction medium had also more than three spots which have very similar $\mathrm{Rf}$ values. After isolation of the openchain target products $6-9$, side products left in the acetic acid. We tried some extraction processes to isolate them, but it was not successful. Therefore, we are planning to use the microwave irradiation technique and using different mole ratios to improve the reaction's yield and time for future study.

Benzamide derivative compounds 6-9 were evaluated towards the AChE enzyme that is one of the targets for the treatment of $A D$. Inhibition results were shown in Table 1. All of the compounds were more effective inhibitors than reference drug Tacrine according to $\mathrm{Ki}$ values. Ki values were in the range of $15.51 \pm 1.88-41.24 \pm 10.13 \mathrm{nM}$ in Table 1. The compounds 6-9 were 1.2-3.2 times more potent than Tacrine $(\mathrm{Ki}=49.23 \pm 2.67 \mathrm{nM})$ in terms of $\mathrm{Ki}$ values. 

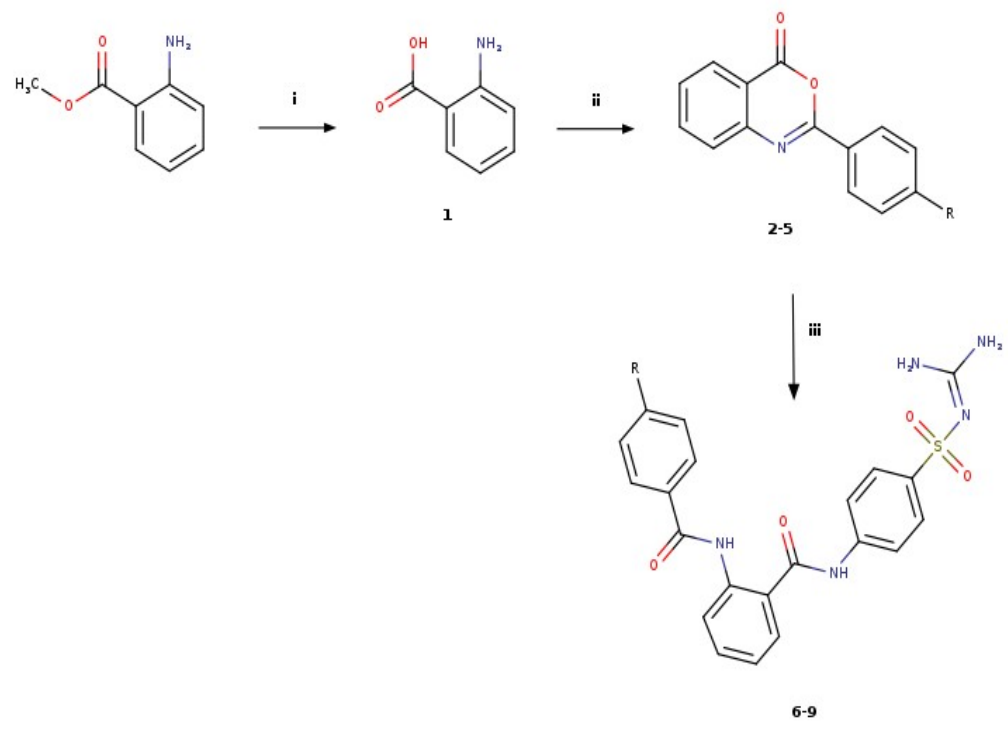

Figure 1. Synthetic method of the target compounds 6-9.

Reagents and conditions. i : $\mathrm{NaOH}$ solution $(2 \mathrm{~N}), \mathrm{HCl}(37 \%)$, rt. ii: Benzoyl chloride derivative $(\mathrm{R}=\mathrm{H}-(6),-\mathrm{OCH} 3(7),-\mathrm{F}(8),-\mathrm{CF} 3(9))$, pyridine, $0-5{ }^{\circ} \mathrm{C}, \mathrm{NaHCO} 3(10 \%)$. iii: Sulfaguanidine, acetic acid, reflux.

The nonsubstituted compound $\mathbf{6}$ was the most promising AChE inhibitor among others. Substitution of methoxy (for 7), fluoro (for 8), and trifluoromethylene (for 9) groups on phenyl ring decreased the enzyme inhibitory potency in 2.4, 2.6, and 2.7 times compared to parent compound $\mathbf{6}$, respectively. Substitution of the para position of phenyl ring with different groups led to decrease inhibition potency. Fluorine substitution is one of the useful modifications in medicinal chemistry to increase bioactivity, bioavailability, stability, and lipophilicity of the compounds (19-21). However, in our study, using halogen substituents did not improve bioactivity significantly when compared to compound 6. Even three of the compounds moderately inhibited, they are effective at the nanomolar level towards AChE enzyme when compared to the reference drug.

Table 1. AChE enzyme inhibitory results of the compounds.

\section{Code Chemical Formula AChE, Ki (nM)}

6

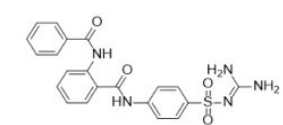

7



8

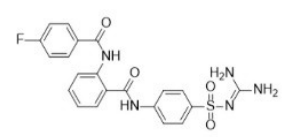

9

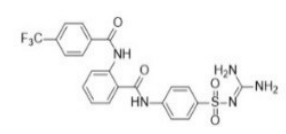

$15.51 \pm 1.88$

$37.39 \pm 6.38$

$39.55 \pm 10.23$

$41.24 \pm 10.13$ 


\section{CONCLUSION}

Here we reported synthesis, structure elucidation, and AChE enzyme inhibitory studies of a small series of novel benzamide derivatives having sulfaguanidine moiety. According to spectroscopic results, we obtained an open-chain structure of the compounds instead of quinazolinone derivatives. The compounds showed nanomolar inhibition level towards the AChE enzyme. The results indicated that compound $\mathbf{6}$ had remarkable inhibitory potency with the lowest Ki value compared to reference drug Tacrine. Therefore, the lead compound $\mathbf{6}$ can be evaluated on different targets of $A D$ in future studies.

\section{ACKNOWLEDGEMENTS}

We would like thank to Prof. Dr. Ilhami Gulcin for his valuable scientific supports.

\section{CONFLICT OF INTEREST}

The authors declare that they have no conflict of interest.

\section{REFERENCES}

1. Wajid S, Khatoon A, Khan MA, Zafar H, Kanwal S et al. Microwave-assisted organic synthesis, structure-activity relationship, kinetics and molecular docking studies of non-cytotoxic benzamide derivatives as selective butyrylcholinesterase inhibitors. Bioorganic and Medicinal Chemistry. 2019;27(18): 4030-40. doi: 10.1016/j.bmc.2019.07.015.

2. Kratky M, Stepankova S, Vorcakova K, Svarcova $M$, Vinsova J. Novel cholinesterase inhibitors based on O-aromatic N,N-disubstituted carbamates and thiocarbamates. Molecules. 2016;21(2): 191-201. doi: 10.3390/molecules21020191.

3. Oliveira C, Bagetta D, Cagide F, Teixeira J, Amorim R, Silva $T$, et al. Benzoic acid-derived nitrones: A new class of potential acetylcholinesterase inhibitors and neuroprotective agents. European Journal of Medicinal Chemistry. 2019;174:116-29.

10.1016/j.ejmech.2019.04.026.

4. Peng DY, Sun Q, Zhu XL, Lin HY, Chen Q, Yu NX, et al. Design, synthesis, and bioevaluation of benzamides: novel acetylcholinesterase inhibitors with multi-functions on butylcholinesterase, $A \beta$ aggregation, and $\beta$-secretase. Bioorganic and Medicinal Chemistry. 2012;20(22):6739-50. doi: 10.1016/j.bmc.2012.09.016.

5. https://www.nia.nih.gov/health/how-alzheimersdisease-treated, December 2020.

6. Darras FH, Kling B, Sawatzky E, Heilmann J, Decker M. Cyclic acyl guanidines bearing carbamate moieties allow potent and dirigible cholinesterase inhibition of either acetyl- or butyrylcholinesterase. Bioorganic and Medicinal Chemistry. 2014;22(17):5020-34. doi: 10.1016/j.bmc.2014.06.010.

7. Yiannopoulou KG, Papageorgiou SG. Current and future treatments for Alzheimer's disease. Therapeutic Advances in Neurological Disorders. 2013;6(1):19-33. doi: 10.1177/1756285612461679.

8. Sekutor M, Mlinaric-Majerski K, Hrenar T, Tomic S, Primozic I. Adamantane-substituted guanylhydrazones: novel inhibitors of butyrylcholinesterase. Bioorganic Chemistry. 2012;41-42:28-34. 10.1016/j.bioorg.2012.01.004.

9. Gul HI, Yamali C, Bulbuller M, Kirmizibayrak PB, Gul $M$, Angeli $A$, et al. Anticancer effects of new dibenzenesulfonamides by inducing apoptosis and autophagy pathways and their carbonic anhydrase inhibitory effects on hCA I, hCA II, hCA IX, hCA XII isoenzymes. Bioorganic Chemistry. 2018;78:290-97. doi: 10.1016/j.bioorg.2018.03.027.

10. Gul HI, Yamali C, Sakagami H, Angeli A, Leitans J, Kazaks A, et al. New anticancer drug candidates sulfonamides as selective hCA IX or hCA XII inhibitors. Bioorganic Chemistry. 2018;77:411-19. doi: 10.1016/j.bioorg.2018.01.021.

11. Yamali C, Gul HI, Ece A, Taslimi P, Gulcin I. Synthesis, molecular modeling, and biological evaluation of 4-(5-aryl-3-(thiophen-2-yl)-4,5-dihydro1 H-pyrazol-1-yl) benzenesulfonamides toward acetylcholinesterase, carbonic anhydrase I and II enzymes. Chemical Biology and Drug Design. 2018;91(4):854-66. doi: 10.1111/cbdd.13149.

12. Yamali C, Gul HI, Kazaz C, Levent S, Gulcin I. Synthesis, structure elucidation, and in vitro pharmacological evaluation of novel polyfluoro substituted pyrazoline type sulfonamides as multitarget agents for inhibition of acetylcholinesterase and carbonic anhydrase I and II enzymes. Bioorganic Chemistry. 2020;96:103627.

10.1016/j.bioorg.2020.103627.

13. Zhu J, Yang HY, Chen Y, Lin HZ, Li Q, Mo J, et al. Synthesis, pharmacology and molecular docking on multifunctional tacrine-ferulic acid hybrids as cholinesterase inhibitors against Alzheimer's disease. Journal of Enzym Inhibition and Medicinal Chemistry. 2018;33(1):496-06. doi: 10.1080/14756366.2018.1430691.

14. Asundaria ST, Patel NS, Patel KC. Synthesis, characterization, and antimicrobial studies of novel 1,3,4-thiadiazolium-5-thiolates. Medicinal Chemistry Research. 2012;21:1199-06. doi: 10.1007/s00044011-9632-2.

15. Ellman GL, Courtney KD, Andres V, Jr., FeatherStone RM. A new and rapid colorimetric determination of acetylcholinesterase activity. 
Biochemical Pharmacology. 1961;7:88-95. doi: 10.1016/0006-2952(61)90145-9.

16. Yamali C, Gul HI, Demir Y, Kazaz C, Gulcin I. Synthesis and bioactivities of 1-(4-hydroxyphenyl)-2((heteroaryl) thio) ethanones as carbonic anhydrase I, II and acetylcholinesterase inhibitors. Turkish Journal of Chemistry. 2020; 44(4), 1058-67. doi:10.3906/kim-2004-36.

17. Yamali C, Gul HI, Cakir T, Demir Y, Gulcin I. Aminoalkylated Phenolic Chalcones: Investigation of Biological Effects on Acetylcholinesterase and carbonic anhydrase I and II as potential lead enzyme inhibitors. Letters in Drug Design and Discovery. 2002;17(10): 1283-92. doi $10.2174 / 1570180817999200520123510$.

18. Selvam $P$, Vijayalakshimi $P$, Smee DF, Gowen BB, Julander JG, Day CW, et al. Novel 3-sulphonamidoquinazolin-4(3H)-one derivatives: microwaveassisted synthesis and evaluation of antiviral activities against respiratory and biodefense viruses. Antiviral Chemistry and Chemotherapy.
2007;18(5):301-5.

doi: $10.1177 / 095632020701800506$.

19. Gillis EP, Eastman KJ, Hill MD, Donnelly DJ, Meanwell NA. Applications of fluorine in medicinal chemistry. Journal of Medicinal Chemistry. 2015;58(21):8315-59. doi:

10.1021/acs.jmedchem.5b00258.

20. Yamali C, Gul HI, Ozgun DO, Sakagami H, Umemura N, Kazaz C, et al. Synthesis and cytotoxic activities of difluoro-dimethoxy chalcones. Anticancer Agents in Medicinal Chemistry. 2017;17(10):1426-33.

doi: $10.2174 / 1871520617666170327123909$.

21. Yamali C, Ozgun DO, Gul HI et al. Synthesis and structure elucidation of 1-(2,5/3,5-difluorophenyl)-3(2,3/2,4/2,5/3,4-dimethoxyphenyl)-2-propen-1-ones as anticancer agents. Medicinal Chemistry Research 2017;26:2015-23. doi: 10.1007/s00044-017-1911-0. 